\title{
Interleukin-27 rs I53109 polymorphism and the risk of non-small-cell lung cancer in a Chinese population
}

This article was published in the following Dove Press journal:

OncoTargets and Therapy

23 February 2016

Number of times this article has been viewed

\author{
Peng $\mathrm{Ge}^{\prime}$ \\ Gangfeng Xiao \\ 'Department of Laboratory, Tianjin \\ Medical University Cancer Institute \\ and Hospital, National Clinical \\ Research Center for Cancer, Key \\ Laboratory of Cancer Prevention \\ and Therapy, Tianjin, ${ }^{2}$ Department of \\ Hematology and Oncology, Ningbo \\ No 2 Hospital, Ningbo Medical \\ University, Ningbo, Zhejiang, People's \\ Republic of China
}

\begin{abstract}
Non-small-cell lung cancer (NSCLC) has a multifactorial pathogenesis, and the genetic background may be one of the critical etiologic factors. Interleukin (IL)-27, a novel member of the IL-12 family, plays a vital role in antitumor immunity. The aim of the current study was to determine the association of a single nucleotide polymorphism of the $I L-27$ gene with the risk of NSCLC. The genotype of the IL-27 rs153109 polymorphism was analyzed in 388 patients with NSCLC and 390 healthy controls by using polymerase chain reaction-restriction fragment length polymorphism and DNA sequencing methods. In the patients with NSCLC, the frequencies of the GG, GA, and AA genotypes and the $\mathrm{G}$ and A alleles were $14.0 \%, 56.4 \%$, $29.6 \%, 42.1 \%$, and $57.9 \%$, respectively. There were no significant differences in the genotype and allele distributions of the IL-27 rs153109 polymorphism between the patients with NSCLC and healthy controls $(P>0.05)$. Furthermore, no association was determined between this polymorphism and different clinical characteristics in patients with NSCLC. Taken together, these findings suggest that the $I L-27$ gene may not be involved in the development of NSCLC in the Chinese population.
\end{abstract}

Keywords: IL-27, polymorphism, NSCLC

\section{Introduction}

Lung cancer is the leading cause of human cancer deaths worldwide. Most patients are diagnosed with advanced, unresectable disease and have a poor prognosis. The overall 5-year survival rate of patients with lung cancer is $<16 \%$. $^{1}$ The etiology of lung cancer has not yet been fully elucidated. However, it is accepted that the pathogenesis of lung cancer is multifactorial and that the genetic background may be one of the critical etiologic factors.

Interleukin (IL)-27, a novel member of the IL-12 family, has been reported to play a vital role in antitumor immunity. ${ }^{2}$ The $I L-27$ gene is located on chromosome 16 (16p11) and comprises two subunits: Epstein-Barr virus-induced gene 3 (EBI3) and p28. IL-27 not only exhibits antitumor immune activity via cytotoxic T-lymphocytes and natural killer cells but also shows an antiangiogenic effect against melanoma. ${ }^{3}$ The antitumor activity of IL-27 in a murine model of colon carcinoma has been shown to be mediated through $\mathrm{CD}^{+} \mathrm{T}$-cells with enhanced cytotoxic T-lymphocyte activity. ${ }^{4}$ IL-27 plays an important role in the antitumor activity against lung cancer by inhibiting epithelialmesenchymal transition and angiogenic factor production via a STAT1-dominant pathway and/or suppressing cyclooxygenase-2-mediated activities. ${ }^{5-8}$

Recently, polymorphisms in the $I L-27$ gene have been evaluated in patients with nasopharyngeal carcinoma, colorectal cancer, and hepatocellular carcinoma. ${ }^{9-11}$ To date,
Correspondence: Gangfeng Xiao Department of Hematology and Oncology, Ningbo No 2 Hospital, Ningbo Medical University, No 4I Xibei Street, Ningbo, Zhejiang 315010, People's Republic of China

Tel +8657483870268

Email xiaogangfeng123@I63.com 
little is known about the role of IL-27 polymorphisms in the risk of non-small-cell lung carcinoma (NSCLC) development. Therefore, in the present study, we determined whether the IL-27 rs153109 polymorphism was associated with NSCLC in a cohort of Chinese patients with lung cancer.

\section{Materials and methods Subjects}

We recruited 388 patients with NSCLC and 390 cancer-free healthy controls in this study. The diagnosis of NSCLC was established by histopathological examination of biopsy or surgically resected tissue specimens. The cancer-free healthy controls were recruited from individuals who underwent routine health examinations at the Department of Health. At the beginning of the study, the patients had not been treated with any anticancer medication. The following data were recorded: sex, age at admission, smoking status, lymph node metastasis, histological type, and clinical stage. The study was approved by the Ningbo No 2 Hospital Ethics Committee. Written informed consent was obtained from all subjects. The main characteristics of the subjects are presented in Table 1.

\section{Extraction of genomic DNA}

Peripheral blood samples were collected in vacuum tubes containing 5\% ethylenediaminetetraacetic acid (EDTA). Genomic DNA was extracted using a DNA Purification Kit (Tiangen Biotech[Beijing]Co., Ltd., Beijing, People's Republic of China) according to the manufacturer's instructions.

Table I The clinical characteristics of the subjects, including patients with NSCLC and healthy controls

\begin{tabular}{|c|c|c|c|}
\hline Characteristics & $\begin{array}{l}\text { No of } \\
\text { patients (\%) }\end{array}$ & $\begin{array}{l}\text { No of } \\
\text { controls (\%) }\end{array}$ & $P$-value \\
\hline \multicolumn{4}{|l|}{ Sex } \\
\hline Female & $246(63.4)$ & $231(59.2)$ & 0.23 \\
\hline Male & $142(36.6)$ & $159(40.8)$ & \\
\hline \multicolumn{4}{|l|}{ Age (years) } \\
\hline$\leq 60$ & $120(30.9)$ & $133(34.1)$ & 0.34 \\
\hline$>60$ & $268(69.1)$ & $257(65.9)$ & \\
\hline \multicolumn{4}{|l|}{ Smoking status } \\
\hline Yes & $294(75.8)$ & $292(74.9)$ & 0.77 \\
\hline No & $94(24.2)$ & $98(25.1)$ & \\
\hline \multicolumn{4}{|l|}{ Histological type } \\
\hline Squamous carcinoma & $226(58.2)$ & & \\
\hline Adenocarcinoma & $162(4 \mid .8)$ & & \\
\hline \multicolumn{4}{|l|}{ Lymph node metastasis } \\
\hline Yes & $134(34.5)$ & & \\
\hline No & $254(65.5)$ & & \\
\hline \multicolumn{4}{|l|}{ Clinical stage } \\
\hline $\mathrm{I}+\mathrm{II}$ & $83(21.4)$ & & \\
\hline$I I I+I V$ & $305(78.6)$ & & \\
\hline
\end{tabular}

Abbreviation: NSCLC, non-small-cell lung cancer.
IL-27 genotyping by polymerase chain reactionrestriction fragment length polymorphism

Genotyping of the IL-27 rs153109 polymorphism was performed using polymerase chain reaction (PCR)-restriction fragment length polymorphism. The forward primer 5'-CTGATCCTGACCTCACT CAACGC-3' and the reverse primer 5'-CTGACTGG GACTGGGACTCAGC-3' were used for PCR. A $20-\mu \mathrm{L}$ volume of the PCR mixture contained 50-150 ng genomic DNA and $10 \mu \mathrm{L}$ of $2 \times$ PCR mix (Tiangen Biotech[Beijing]Co., Ltd.). For PCR amplification, an initial denaturation at $94^{\circ} \mathrm{C}$ for 5 minutes was followed by 36 cycles at $94^{\circ} \mathrm{C}$ for 30 seconds, at $64^{\circ} \mathrm{C}$ for 30 seconds, at $72^{\circ} \mathrm{C}$ for 30 seconds, and a final extension at $72^{\circ} \mathrm{C}$ for 10 minutes. BstUI (New England Biolabs, Beverly, MA, USA) was used to detect A-G transitions. To confirm the genotyping results, PCR-amplified DNA samples were examined by DNA sequencing, and the results were $100 \%$ concordant.

\section{Statistical analysis}

Statistical analysis was performed using SPSS statistical software Version 18.0. The genotype distribution and frequencies were analyzed using the chi-squared test. Differences were considered statistically significant at $P<0.05$.

\section{Results}

The mean ages of the 388 patients with NSCLC and 390 healthy controls were 64.2 and 62.8 years, respectively. The patient with NSCLC cohort consisted of $63.4 \%$ women and $36.6 \%$ men. Most patients with NSCLC had squamous cell carcinoma (58.2\%), and the remaining had adenocarcinoma (41.8\%). The clinical stage was I or II in $21.4 \%$ of the patients with NSCLC and III or IV in $78.6 \%$ of patients. The clinical characteristics of the subjects have been shown in Table 1.

In this study, the genotype and allele frequencies of the IL-27 rs153109 polymorphism were detected in both the patients with NSCLC and healthy controls, and no significant differences were found between the two groups of subjects (Table 2). Furthermore, to verify the association between the IL-27 rs153109 polymorphism and certain clinical characteristics, we performed stratified analyses in the patients with NSCLC according to sex, age at admission, smoking status, histological type, lymph node metastasis, and clinical stage. However, no statistical differences were detected (Table 3).

\section{Discussion}

Lung cancer is one of the most commonly diagnosed cancers and accounts for $\sim 18 \%$ of all cancer-related deaths worldwide. ${ }^{1}$ NSCLC accounts for $>80 \%$ of all lung cancer cases and 
Table 2 Distribution of the genotype and allele frequencies of IL-27 rsI53109 polymorphism in patients with NSCLC and healthy controls

\begin{tabular}{|c|c|c|c|c|}
\hline \multirow{2}{*}{$\begin{array}{l}\text { IL-27 rs I } 53 \text { I } 09 \\
\text { polymorphism }\end{array}$} & \multicolumn{4}{|l|}{ Frequency } \\
\hline & $\begin{array}{l}\text { NSCLC, } \\
n=388 \text { (\%) }\end{array}$ & $\begin{array}{l}\text { Control, } \\
n=390(\%)\end{array}$ & $x^{2}$ & $P$-value \\
\hline \multicolumn{5}{|l|}{ Genotype } \\
\hline GG & $54(14.0)$ & $48(12.3)$ & 1.23 & 0.54 \\
\hline GA & $219(56.4)$ & $213(54.6)$ & & \\
\hline$A A$ & II 5 (29.6) & $129(33.1)$ & & \\
\hline \multicolumn{5}{|l|}{ Allele } \\
\hline Allele G & $327(42.1)$ & 309 (39.6) & 1.03 & 0.31 \\
\hline Allele A & 449 (57.9) & $471(60.4)$ & & \\
\hline \multicolumn{5}{|l|}{ Genotype } \\
\hline GG or GA & $273(70.4)$ & $26 I(66.9)$ & 1.07 & 0.30 \\
\hline $\mathrm{AA}$ & II (29.6) & $129(33.1)$ & & \\
\hline \multicolumn{5}{|l|}{ Genotype } \\
\hline GG & $54(14.0)$ & $48(12.3)$ & 0.44 & 0.51 \\
\hline $\mathrm{AA}$ or $\mathrm{GA}$ & $334(86.0)$ & $342(87.7)$ & & \\
\hline
\end{tabular}

Abbreviation: NSCLC, non-small-cell lung cancer.

includes two predominant subtypes: adenocarcinoma and squamous cell carcinoma. ${ }^{12}$ Although tobacco smoking is the major risk factor associated with NSCLC, it is critical to understand the contribution of genetic factors in the development of NSCLC.

IL-27 displays antitumor activity via different mechanisms. ${ }^{13}$ It not only exerts antiproliferative and antiangiogenic effects by directly acting on cancer cells but also indirectly mediates antitumor effects via its immune-stimulatory activity in many cancers, including hematologic malignancies ${ }^{14-16}$ and solid tumors ${ }^{17,18}$ such as lung cancer..$^{5-8}$ The IL-27 rs153109 polymorphism is located in the promoter region of the $I L-27$ gene. Recently published data demonstrate that the IL-27 rs 153109 polymorphism is associated with an increased risk of certain cancers, including nasopharyngeal carcinoma, colorectal carcinoma, and hepatocellular carcinoma. ${ }^{9-11}$ To our knowledge, the role of this polymorphism in NSCLC susceptibility is still unclear. Thus, the aim of this study was to determine whether the IL-27 rs153109 polymorphism was associated with an increased risk of NSCLC. In this study, the frequencies of the GG, GA, and AA genotypes and the $\mathrm{G}$ and $\mathrm{A}$ alleles were $14.0 \%, 56.4 \%, 29.6 \%, 42.1 \%$, and $57.9 \%$, respectively. There were no significant differences in the genotype and allele distributions of the IL-27 rs153109 polymorphism between the patients with NSCLC and healthy controls $(P>0.05)$. In addition, no significant differences were found between the two subgroups after stratification by clinical characteristics, such as age, sex, smoking status, histological type, lymph node metastasis, and clinical stage.

In conclusion, our data suggest that the $I L-27$ gene may not be involved in the development of NSCLC in the Chinese population. However, the negative findings obtained in this study may be attributable to differences in populations, subjects, and sample sizes. Therefore, further larger, populationbased studies are needed to explore the role of $I L-27$ gene polymorphisms in the risk of NSCLC, especially, in ethnically different populations.

Table 3 Association between IL-27 rs 153109 polymorphism and clinicopathological characteristics of patients with NSCLC

\begin{tabular}{|c|c|c|c|c|c|c|c|}
\hline \multirow[t]{2}{*}{ Characteristics } & \multirow[t]{2}{*}{ Cases (\%) } & \multicolumn{2}{|c|}{ Genotype no } & \multicolumn{2}{|c|}{ Genotype no } & \multirow[t]{2}{*}{$\chi^{2}$} & \multirow[t]{2}{*}{$P$-value } \\
\hline & & GG (\%) & $\mathbf{G A}+\mathbf{A A}(\%)$ & AA (\%) & GA + GG (\%) & & \\
\hline \multicolumn{8}{|l|}{ Sex } \\
\hline Female & $246(63.4)$ & $38(15.4)$ & $208(84.6)$ & $70(28.5)$ & I76 (7I.5) & $\left.1.3\right|^{\mathrm{a}}$ & $0.25^{\mathrm{a}}$ \\
\hline Male & $142(36.6)$ & $16(11.2)$ & $126(88.7)$ & $45(31.7)$ & $97(68.3)$ & $0.45^{b}$ & $0.50^{\mathrm{b}}$ \\
\hline \multicolumn{8}{|l|}{ Age (years) } \\
\hline$\leq 60$ & $120(30.9)$ & $16(13.3)$ & $104(86.7)$ & $35(29.2)$ & $85(70.8)$ & $0.05^{\mathrm{a}}$ & $0.82^{\mathrm{a}}$ \\
\hline$>60$ & $268(69.1)$ & $38(14.2)$ & $230(85.8)$ & $80(29.9)$ & I $88(70.1)$ & $0.02^{\mathrm{b}}$ & $0.89^{b}$ \\
\hline \multicolumn{8}{|l|}{ Smoking status } \\
\hline Yes & $294(75.8)$ & $43(14.6)$ & $251(85.4)$ & $93(31.6)$ & $201(68.4)$ & $0.5 \mathrm{I}^{\mathrm{a}}$ & $0.48^{\mathrm{a}}$ \\
\hline No & $94(24.2)$ & II (II.7) & $83(88.3)$ & $22(23.4)$ & $72(76.6)$ & $2.31^{\mathrm{b}}$ & $0.13^{b}$ \\
\hline \multicolumn{8}{|l|}{ Histological type } \\
\hline Squamous carcinoma & $226(58.2)$ & $32(14.2)$ & $194(85.8)$ & $69(30.5)$ & $157(69.5)$ & $0.03^{\mathrm{a}}$ & $0.87^{a}$ \\
\hline Adenocarcinoma & $162(41.8)$ & $22(13.6)$ & $140(86.4)$ & $46(28.4)$ & $116(71.6)$ & $0.21^{\mathrm{b}}$ & $0.65^{b}$ \\
\hline \multicolumn{8}{|l|}{ Lymph node metastasis } \\
\hline Yes & $134(34.5)$ & $20(14.9)$ & II4 (85.I) & 40 (29.9) & $94(70.1)$ & $0.17^{\mathrm{a}}$ & $0.68^{\mathrm{a}}$ \\
\hline No & $254(65.5)$ & $34(13.4)$ & $220(86.6)$ & $75(29.5)$ & $179(70.5)$ & $0.004^{b}$ & $0.95^{\mathrm{b}}$ \\
\hline \multicolumn{8}{|l|}{ Clinical stage } \\
\hline$I+I I$ & $83(21.4)$ & II (13.3) & 72 (86.7) & $26(31.3)$ & 57 (68.7) & $0.04^{\mathrm{a}}$ & $0.84^{\mathrm{a}}$ \\
\hline $\mathrm{III}+\mathrm{IV}$ & $305(78.6)$ & $43(14.1)$ & $262(85.9)$ & $89(29.2)$ & $216(70.8)$ & $0.14^{\mathrm{b}}$ & $0.70^{\mathrm{b}}$ \\
\hline
\end{tabular}

Notes: aG compared with GA + AA. ' $A A$ compared with GA + GG.

Abbreviation: NSCLC, non-small-cell lung cancer. 


\section{Acknowledgment}

This work was supported in part by a grant from the Ningbo Natural Science Foundation (2014A610229).

\section{Disclosure}

The authors report no conflicts of interest in this work.

\section{References}

1. Jemal A, Bray F, Center MM, Ferlay J, Ward E, Forman D. Global cancer statistics. CA Cancer J Clin. 2011;61(2):69-90.

2. Hunter CA. New IL-12-family members: IL-23 and IL-27, cytokines with divergent functions. Nat Rev Immunol. 2005;5(7):521-531.

3. Nagai H, Oniki S, Fujiwara S, et al. Antitumor activities of interleukin-27 on melanoma. Endocr Metab Immune Disord Drug Targets. 2010;10(1): $41-46$.

4. Chiyo M, Shimozato O, Yu L, et al. Expression of IL-27 in murine carcinoma cells produces antitumor effects and induces protective immunity ininoculated host animals. Int $J$ Cancer. 2005;115(3):437-442.

5. Kachroo P, Lee MH, Zhang L, et al. IL-27 inhibits epithelial-mesenchymal transition and angiogenic factor production in a STAT1-dominant pathway in human non-small cell lung cancer. J Exp Clin Cancer Res. 2013;32:97.

6. Naumnik W, Naumnik B, Niewiarowska K, Ossolinska M, Chyczewska E. Novel cytokines: IL-27, IL-29, IL-31 and IL-33. Can they be useful in clinical practice at the time diagnosis of lung cancer? Exp Oncol. 2012; 34(4):348-353.

7. Ho MY, Leu SJ, Sun GH, Tao MH, Tang SJ, Sun KH. IL-27 directly restrains lung tumorigenicity by suppressing cyclooxygenase-2-mediated activities. J Immunol. 2009;183(10):6217-6226.

8. Zhang J, Tian H, Li C, et al. Antitumor effects obtained by autologous Lewis lung cancer cell vaccine engineered to secrete mouse interleukin 27 by means of cationic liposome. Mol Immunol. 2013;55(3-4): 264-274.
9. Huang ZQ, Wang JL, Pan GG, Wei YS. Association of single nucleotide polymorphisms in IL-12 and IL-27 genes with colorectal cancer risk. Clin Biochem. 2012;45(1-2):54-59.

10. Wei YS, Lan Y, Luo B, Lu D, Nong HB. Association of variants in the interleukin-27 and interleukin-12 gene with nasopharyngeal carcinoma. Mol Carcinog. 2009;48(8):751-757.

11. Peng Q, Qin X, He Y, et al. Association of IL27 gene polymorphisms and HBV-related hepatocellular carcinoma risk in a Chinese population. Infect Genet Evol. 2013;16:1-4.

12. Dutt A, Ramos AH, Hammerman PS, Mermel C, Cho J, Sharifnia T. Inhibitor-sensitive FGFR1 amplification in human non-small cell lung cancer. PLoS One. 2011;6(6):e20351.

13. Murugaiyan G, Saha B. IL-27 in tumor immunity and immunotherapy. Trends Mol Med. 2013;19(2):108-116.

14. Cocco C, Giuliani N, Di Carlo E, Ognio E, Storti P, Abeltino M. Interleukin-27 acts as multifunctional antitumor agent in multiple myeloma. Clin Cancer Res. 2010;16(16):4188-4197.

15. Canale S, Cocco C, Frasson C, Seganfreddo E, Di Carlo E, Ognio E. Interleukin-27 inhibits pediatric B-acute lymphoblastic leukemia cell spreading in a preclinical model. Leukemia. 2011;25(12):1815-1824.

16. Cocco C, Di Carlo E, Zupo S, Canale S, Zorzoli A, Ribatti D. Complementary IL-23 and IL-27 anti-tumor activities cause strong inhibition of human follicular and diffuse large B-cell lymphoma growth in vivo. Leukemia. 2012;26(6):1365-1374.

17. Matsui M, Kishida T, Nakano H, et al. Interleukin-27 activates natural killer cells and suppresses NK-resistant head and neck squamous cell carcinoma through inducing antibody-dependent cellular cytotoxicity. Cancer Res. 2009;69(6):2523-2530.

18. Salcedo R, Stauffer JK, Lincoln E, Back TC, Hixon JA, Hahn CJ. IL-27 mediates complete regression of orthotopic primary and metastatic murine neuroblastoma tumors: role for CD8+ T cells. $J$ Immunol. 2004;173(12):7170-7182.
OncoTargets and Therapy

\section{Publish your work in this journal}

OncoTargets and Therapy is an international, peer-reviewed, open access journal focusing on the pathological basis of all cancers, potential targets for therapy and treatment protocols employed to improve the management of cancer patients. The journal also focuses on the impact of management programs and new therapeutic agents and protocols on

\section{Dovepress}

patient perspectives such as quality of life, adherence and satisfaction. The manuscript management system is completely online and includes a very quick and fair peer-review system, which is all easy to use. Visit http://www.dovepress.com/testimonials.php to read real quotes from published authors. 